\title{
Operational-Investigative Activities of Judicial Authorization: Features of Performance
}

\author{
Ahmed Guseinovich Ahmedov ${ }^{1 *}$, Taylan Osmanovic Boziev ${ }^{1}$, Nikolay Kazimirovich \\ Pcholovsky $^{1}$, and Luis Alomar Ocampo Cardenas ${ }^{2}$ \\ ${ }^{1}$ Saint Petersburg University of the Ministry of Internal Affairs of Russia, Department of Operational- \\ Investigative Activities in the Internal Affairs Bodies, Saint Petersburg, Russia \\ ${ }^{2}$ Police Officer of the Drug Enforcement Administration of the National Police, Managua, Nicaragua
}

\begin{abstract}
The scientific article is devoted to the study of issues related to the peculiarities of performing operational-investigative activities of judicial authorization enshrined in the Federal Law "On operational-investigative activities" The questions of performing operational-investigative activities and the restrictions on the constitutional rights of citizens, connected with them, are raised. Performing operational-investigative activities, requiring judicial authorization, is impossible without clear knowledge and understanding of not only the Federal Law "On operational-investigative activities" but also the decisions of both the Constitutional Court and the European Court of Human Rights. Understanding these documents makes it possible to competently and fully, in compliance with all the requirements of the law, draw up the necessary documents to obtain the permission of a court, competently and clearly determine which activity should be conducted in each case, taking into account the technical and other features of both the activity itself and the allocated funds. Purpose: to conduct a scientific study of operational-investigative activities of judicial authorization; to analyze the legislation governing the specifics of performing these activities, the powers of the subjects of operationalinvestigative activities when performing the considered activities. As the methods and methodology of conducting the work, formal-logical and dialectical methods, sociological, and historical methods were used. The scientific article is based on a sociological, theoretical, and historical method, on a set of techniques for understanding the legal status of an official, the theory of authorities, and a comparative analysis of legislative norms. The main methodological approach used in the scientific article is the theory of operational-investigative legislation, developed in the works of Russian lawyers. Main results: the study made it possible to identify the advantages and disadvantages of the regulatory framework governing the specifics of conducting operational-investigative activities requiring judicial authorization, as well as significant errors in law enforcement practice. Conclusions and substantiation of the novelty of the work: based on the analysis of the Federal Law "On operational-investigative activities", insufficient legal elaboration of the legal regulation of operationalinvestigative activities of judicial authorization is substantiated. The ways
\end{abstract}

*Corresponding author: russkif@mail.ru 
of solving the existing problems are proposed, including by amending the current legislation on operational-investigative activities.

Keywords: operational-investigative activity, operational-investigative activities of judicial authorization, operational-investigative legislation, bodies performing operational-investigative activities

\section{Introduction}

Some operational-investigative activities imply an invasion of the privacy of citizens, which is permitted by the operational-investigative legislation in the interests of optimizing the fight against the most dangerous manifestations of crime. These relations are consideredin the Federal Law "On operational-investigative activities" [1]. The recognition of the legality of this group of operational-investigative activities significantly strengthened the position of the operational-investigative bodies and made it possible to use factual materials in the process of substantiation obtained in the course of their conduct. At the same time, when performing operational-investigative activities requiring judicial authorization, the questions arise, which are not directly prescribed in the law, in the course of law enforcement practice, caused also by the emergence of new technical devices, control over which is required to solve the tasks of operational-investigative activities, but at the same time, this is not prescribed in the law.

Analyzing the international experience of scientific research related to the peculiarities of conducting operational-investigative activities limiting the constitutional rights of citizens, one should refer to some works. Thus, one of the scientists, Michael Scheibenreif, in his study "Europol and European Security or how the agency is trying to serve its purpose" [2] considers the ways of improving operational-investigative legislation, the problems of limiting the constitutional rights of citizens while the Europol departments implement operational-investigative activities, as well as their main functions and powers.

Egemberbi Samidinovich Toktorov in his scientific article "Theoretical problems of understanding the essence of operational-investigative activities" [3] reveals the main theoretical problems of limiting the constitutional rights of citizens during operationalinvestigative activities that require restricting the constitutional rights of citizens.

The scientific interest lies in the fact that only certain areas of activities requiring the restriction of the constitutional rights of citizens are legally considered, which causes certain collisions in law, while the available measures do not fully cover all issues related to the restriction of the constitutional rights of citizens.

To resolve conflict-of-law legal issues, a study was conducted among the operational employees of operational departments with the aim of identifying a gap in the law and elaborating recommendations for a law enforcer.

The study involved 243 operational officers; the purpose of the study is to present to the scientific community the options for resolving existing legal issues in the field of operationalinvestigative activities that require judicial authorization.

In the course of the study, an individual methodology for collecting and processing information was used, a questionnaire survey of employees, as well as formal-logical methods, which made it possible to summarize information and draw conclusions on each fact of the study.

The legal basis for the study was the Federal Law "On the police", the Federal Law "On operational-investigative activities", and the information obtained while questioning the employees of the internal affairs bodies. 


\section{Formulation of the problem}

In the context of rapidly changing legislation and law enforcement practice, the institution of operational-investigative activities requiring judicial authorization remained practically unchanged. This testifies either to the competent legal consolidation of this institution or to the fact that, on the contrary, this institution does not work fully as it should. At the same time, it should be borne in mind that the conduct of operational-investigative activities that require judicial authorization and therefore limit the constitutional rights of citizens is not only necessary and required in the fight against crime but is also important from the point of view of the civil society, since it is intended to foster in citizens an understanding of responsibility to observe law and order and encourage the population to respond more clearly to the committed crimes [4], i.e. in other words, involve the population in the fight against crime.

One of the main issues is the question of observing the rights of citizens to the inviolability of their homes.

Considering the provision of the first part of Article 6 in unity with the prescription of the second part of Article 8, the Constitutional Court notes that when performing any operationalinvestigative activities, including surveillance, the constitutional right of a citizen to the inviolability of their homes cannot be limited without a court decision, i.e. it is prohibited to enter the home except for on the basis of a court decision; performing such operationalinvestigative activities is possible only on the grounds provided for by this norm, and only in connection with such an act for which the production of a preliminary investigation is mandatory. The admissibility of limiting the rights to the secrecy of telephone conversations and the inviolability of the home on the basis of a court decision is established directly by the Constitution of the Russian Federation (Part 2 of Art. 23 and Art. 25) [5].

Part 2, Article 8 of the Federal Law "On operational-investigative activities" establishes that the conduct of operational-investigative activities restricting the right to the inviolability of the home is allowed on the basis of a court decision and in the presence of information: regarding the signs of a wrongful act for which the preliminary investigation is mandatory; regarding persons preparing, committing or having committed such an unlawful act; regarding events or actions that pose a threat to the state, military, economic, or environmental security of the Russian Federation.

It should also be taken into account that the rapidly changing information world poses new tasks and new problems, respectively, the current legislation does not keep pace with these changes and thus while discussing operational-investigative activities requiring judicial authorization, it should be stated that their list will initially lag behind from the objective world, and accordingly there will be those who will claim that their rights have been violated[6]. If this is the case, then it is required to raise the question that it is time to remove the list of operational-investigative activities and be limited to the possibility of restricting the rights of citizens through obtaining judicial authorization in the event of restricting these rights.

\section{Results}

Speaking about operational-investigative activities requiring judicial authorization, the authors come to the conclusion that the list available today does not fully correspond to the emerging practice, both legal and daily. Quite a lot of questions are raised, for example, regarding such activities as obtaining computer information [7].

Undoubtedly, the concept of computer information is enshrined in Note 1 to Article 272 of the Criminal Code of the Russian Federation, where computer information is understood as information (messages, data) presented in the form of electrical signals, regardless of the 
means of their storage, processing, and transmission. Thus, computer information is a type of information in a form that provides processing of electrical signals in computer devices, its transmission through communication channels, or storage on specialized media. The category of computers includes structurally different devices designed for automated processing of digitized data (personal and network computers, servers, laptops, cell phones, smartphones, tablets, etc.) [8].

Obtaining operatively significant computer information involves the examination of information objects on the Internet containing information about the commission of crimes and the persons committing them (websites of criminal structures through which socially dangerous information is disseminated, objects prohibited for circulation are sold, a criminal lifestyle is promoted, and new participants get involved in illegal activities, etc.). Among other sources of operatively significant computer information, one should indicate the network communication channels used by criminals to coordinate actions using e-mail, means of exchanging messages, VoIP applications (Internet telephony), messengers, etc[9].

However, a key question arises, how the access to this information is obtained, for example, it should be stored only on a computer, or in cloud storage, or in the memory of a smartphone, etc.

In connection with the above-mentioned, it seems that the legal field should enshrine the right of bodies performing operational-investigative activities to limit the constitutional rights of citizens, without a list of these activities, the list of which should be regulated by departmental legal acts.

\section{Conclusion}

In the authors' opinion, in order to avoid double, triple, and other interpretations of the norms of legislation on operational-investigative activity, especially in terms of limiting the constitutional rights of citizens and, accordingly, limiting their constitutional rights and freedoms, it is required to indicate in the legislation the very possibility of bodies performing operational-investigative activities to restrict these rights, which require judicial authorization, but to remove their list from the law, due to the fact that the technical component is rapidly changing in the world, and the legislator does not always keep up with it, and accordingly, the law enforcer does not have time to adequately counter crime, for which it was created.

Practical significance consists in determining the possibility of increasing the efficiency of the institution of operational-investigative activities that require judicial authorization and, therefore, restricting the constitutional rights of citizens, as well as the elaboration of a mechanism for countering socially dangerous acts by developing additional tools regulating the normative procedure for the application of operational-investigative activities, requiring judicial authorization and, accordingly, regulating the operational-investigative activity for the law enforcer.

Scientific novelty: the article describes the authors' approach to operational-investigative activities that require judicial authorization. The authors proceed from the fact that in the current legislation, it is required to change the list of operational-investigative activities and indicate that the bodies performing operational-investigative activities have the right to restrict the constitutional rights of citizens, with the obligatory obtaining of judicial permission for this. This is especially important due to the fact that from the point of view of the constitution, practically any operational-investigative activities to one degree or another limit the constitutional rights of citizens. 


\section{References}

1. Collection of Legislation of the Russian Federation 33, Item 3349 (1995, August 14)

2. M. Scheibenreif, Europol and European Security or how the agency is trying to serve its purpose (University of Vienna, Vienna, 2009)

3. E.S. Toktorov, Theoretical problems of understanding the essence of operationalinvestigative activities, Theoretical \& Applied Science 11(91), 272-275 (2020)

4. S. Nevala, K. Aromaa (eds.), Organized crime, trafficking, drugs: selected papers presented at the Annual Conference of the European Society of Criminology, Helsinki, 2003 (European Institute for Crime Prevention and Control, Helsinki, 2004)

5. O.A. Vagin, A.E. Chechetin, A.V. Shakhmatov, Operativno-rozysknaya deyatelnost v resheniyakh Konstitutsionnogo Suda Rossiiskoi Federatsii: Uchebnoe posobie [Operational-investigative activity in the decisions of the Constitutional Court of the Russian Federation: Textbook] (St. Petersburg University of the Ministry of Internal Affairs of Russia, Saint Petersburg, 2009)

6. A.G. Akhmedov, T.O. Boziev, N.N. Bukharov N.N. et al., Teoreticheskie osnovy operativno-rozysknoi deyatelnosti. Uchebnoe posobie [Theoretical foundations of operational-investigative activity. Textbook] (Publishing House of St. Petersburg University of the Ministry of Internal Affairs of Russia, Saint Petersburg, 2019)

7. N.N. Bukharov, A.V. Shakhmatov, V.M. Egorshin, A.I. Kurtak, Pravovoi status dolzhnostnogo litsa, osushchestvlyayushchego operativno-rozysknuyu deyatelnost $\mathrm{v}$ organakh vnutrennikh del. Uchebno-metodicheskoe posobie [The legal status of an official performing operational-investigative activities in the Internal Affairs Bodies. Study guide] (Publishing House of St. Petersburg University of the Ministry of Internal Affairs of Russia, Saint Petersburg, 2020)

8. Federalnyi zakon "Ob operativno-rozysknoi deyatelnosti" v skhemakh i akty konstitutsionnogo sudoproizvodstva. Uchebnoe naglyadnoe posobie [Federal Law "On operational-investigative activity" in the schemes and acts of constitutional proceedings. Educational visual aid] (Publishing House of St. Petersburg University of the Ministry of Internal Affairs of Russia, Saint Petersburg, 2019)

9. Nauchno-prakticheskii kommentarii k Federalnomu zakonu "Ob operativno-rozysknoi deyatelnosti" [Scientific and practical commentary to the Federal Law "On Operational-Investigative Activities”] (Publishing House of St. Petersburg University of the Ministry of Internal Affairs of Russia, Saint Petersburg, 2011) 